\title{
Rural development in Belarus: the "agrogrodok": between rural and urban?
}

\author{
Liudmila Slivinskaya ${ }^{1,1}$ \\ ${ }^{1}$ Technische Universität Darmstadt, Faculty of Architecture, Mundus Urbano International Coop- \\ eration in Urban Development, Darmstadt, Germany.
}

\begin{abstract}
The article explores a phenomenon of agrogorodok originated and implemented as state policy of rural revitalization in the former Soviet country of Belarus beginning with 2005-2010 State Programme for Rural Revival \& Development and continuing in further 5-years programmes up till now. The term "agrogorodok" is defined as a new type of rural settlement which features public facilities, industrial, social and transport infrastructures to ensure a high (here: compared to urban) standard of living for its residents and residents of adjacent territories [1]. Wherein in terms of population it remains well below the size of a town and belongs to the lowest level of rural settlements. Currently over 1500 such settlements have been created (against targeted number of 1481 till 2010 as set in [1]). The article is to assess critically the policy against the so-called heroic tradition of modernist thinking to reform way of living via large-scale top-down state-led planning projects combining affordable housing, built public infrastructure as applied to declining rural areas. Further, for the current discourse on territorial development is focused almost exclusively on urbanisation, such specific approach targeting rural while having in its core the idea of some sort of urbanisation (understood as approaching urban standard of living in rural areas) is needed to be conceptualised to find its place in addressing and reinventing rurality in urban world. Such invention of a new type aiming at reconciling urban and rural is to be defined and conceptualised as a contribution into typology. The historical context of a post-soviet country, where continued aggressive state intervention into inter alia rural areas had produced distinct configurations of rural settlements in their transition from traditional to modern, also enriches such exploration of transformative power of ideologies / policy towards landscape. The article, tracing almost 15 years of policy implementation, reveals yet one more failed promise of salvation grinning through the gap between concept and its real appearance.
\end{abstract}

\section{Introduction}

The current discourse on rural development is tied closely to the dominating phenomenon of urbanisation, these two processes being two sides of the same coin of world development in general, or as Rem Koolhaas states it: "Half of mankind lives in the city,

\footnotetext{
${ }^{1}$ Corresponding author: slivinskayalv@gmail.com; liudmila.slivinskaya@stud.tu-darmstadt.de
} 
but the other half doesn't" [2]. In methodological terms these notions often appear in binary opposition, where each is defined against the other.

How do we unite these two halves - rural and urban - in a meaningful way within a common discourse on human habitat? By saying "between rural and urban" we open up the entire terminological and methodological abyss of defining boundaries of a city, territorial limits of urbanisation and even the very possibility of such limits and substantial non-self-referential distinction between them.

Such a distinction between rural and urban has long been present as a research subject across many different fields. First of all, we should refer to urban sociology here, in particular the concept of the rural-urban continuum which can be dated as far back as the $19^{\text {th }}$ century thinking of Ferdinand Tonnies and his dual concept of gemeinschaft (community) and gesellschaft (association) [3] and further developed in the $20^{\text {th }}$ century within the Chicago School and seminal essay by Louis Wirth "Urbanism as a Way of Life" (published in American Journal of Sociology, 1938). The debates, rethinking and reinvention of the concept still continue. The core criteria to distinguish both notions as applied within this school of thinking are the sociological characteristics, particular way of life different types of settlements offer.

The subject of rural-urban has also been explored in settlement geography, planning and economics inter alia. Given the limited scope of this paper, the focus however will be placed away from sociology toward planning policies/practices and the development discourse in general as it defines urbanisation and searches for criteria to back up its definition. The approach adopted by United Nations agencies relevant to urban development will be referred for this purpose. Thus, the UN Department of Economic and Social Affairs [UNDEaSA] in its World Urbanisation Prospects gives the following description of rural-urban: "the criteria for classifying an area as urban may be based on one or a combination of characteristics, such as: a minimum population threshold; population density; proportion employed in non-agricultural sectors; the presence of infrastructure such as paved roads, electricity, piped water or sewers; and the presence of education or health services" [4]. The challenge for universal or at least comparable definition for the purposes of a global urban development discourse is tackled here through the recognition of a multitude of national approaches such as "National definitions are most commonly based on size of locality. Population which is not urban is considered rural" [5].

Furthermore, the UN Principles and Recommendations for Population and Housing Censuses [6], recognising the virtual impossibility of a single definition due to such national differences, draws attention to the fact that whereas the traditional distinction between rural and urban had been based on the different quality of life in both of them, "In many developed countries, this distinction has become blurred and the principal difference between urban and rural areas in terms of the circumstances of living tends to be a matter of the degree of concentration of population." [6: 188]. Further, the same document suggests that: "although the traditional urban-rural dichotomy is still needed, classification by size of locality can usefully supplement the dichotomy or even replace it where the major concern is with characteristics related only to density along the continuum from the most sparsely settled areas to the most densely built-up localities" [lbid.]. Such an approach to a new degree of urbanisation defined through the level of density/concentration had been suggested, for example, to address European urbanisation by DG REGIO [7], for it is no longer relevant to draw distinction based on infrastructure and service provision and correspondingly the different quality of life offered. To capture conceptually new territorial formations across EU the cluster approach had 
been suggested within which Urban Morphological Zones, Urban Clusters and Centres, as well as Rural Grid Cells had been outlined based on density:

1. Densely populated area: (alternative name: cities). At least $50 \%$ living in highdensity clusters (alternative name: urban centre);

2. Intermediate density area (alternative name: towns and suburbs). Less than 50 $\%$ of the population living in rural grid cells; and less than $50 \%$ living in a highdensity cluster;

3. Thinly populated area (alternative name: rural area). More than $50 \%$ of the population living in rural grid cells [7: 5].

These efforts on rethinking the classification of settlements under the rural-urban criteria are caused by transformations, merging and fluid relations of settlements formations in the conditions of today's urbanisation.

However, if we are to look to rapidly urbanising developing world, can we rely on the same assumptions and shift from quality of life to population concentration? For if we are to compare the level of infrastructure and access to services across wider territories not necessarily labelled as urban in some highly developed countries to the quality of life in sprawling informal districts in megacities of developing countries, it becomes evident that reliance on one criterion could be insufficient and irrelevant for different contexts. However, the need for at least degree of unity for comparison and generalisation purposes needs to be achieved, which makes the efforts toward proper general conceptualisation of rural-urban rather relevant. Within such a debate the attention could be put to the relations of the two criteria discussed above, which could be broadly grouped under two approaches, one being demographics (population size/ density) and the other being level of infrastructure/service provision (quality of life).

This being said, the case study referred to here - as highlighted in the title, the questioned position of an agrogorodok in-between rural and urban - is seen then as illustrative within the above focus and is explored to unpack the relations between these two approaches with all reservations being made into scale, local historical and contextual specific etc.

\section{The Belarussian "agrogorodok"}

\section{Definition}

The term agrogorodok refers here to a kind of hybrid of rural and urban. Its literal translation would be "agro-town", wherein "agro" means belonging to rural/ agriculture, and gorodok means "small town". Its official definition is "a new type of rural settlement which features public facilities, industrial, social and transport infrastructures to ensure a high [here: compared to urban] standard of living for its residents and residents of adjacent territories" [1].

The concept originated and has been implemented as state policy of rural revitalisation in Belarus beginning with the 2005-2010 State Programme for Rural Revival and Development [1] and has continued up to the present day through further 5-year programmes across different sectors such as the 2016-2020 State Programme for Agriculture Business/Farming Development [8]; the promotion of agro-eco-tourism, housing policy and others, retaining an important place in the overall state development strategy. 


\section{Belarussian Soviet-era context}

The context for such state policy is that of a post-Soviet country with nearly 20 years of independence and a being in a transitional condition from a disrupted system of planned command economy, which moreover was extended not only onto the national level but the supranational one of the Soviet Union as a totality. In terms of rural development policy, the country underwent the same processes of mass collectivisation, mechanisation of agriculture along with industrialisation of production as had been carried out across the Soviet Union. As regards some specific features of rural development during Soviet times in terms of rural settlement distribution, if we look back at over 50 years of history of state intervention in rural areas in Belarus, we can see the policy of so-called "consolidation/ enlargement" of rural settlements having started in the end of the 1950s - beginning of 1960s to increase the efficiency of state subsidies into rural areas. In that respect, small-sized settlements were predominant at that time in rural areas of Belarus: $76 \%$ of settlements had a population of less than 200; moreover, types of settlements such as hamlets/farmsteads was widespread - around 150 thousand such settlements existed [9].

The new enlargement policy was designed to consolidate the rural population around collective farming centres (kolkhoz). To that end therefore, all settlements were classified based on their size as "promising" or "non-promising" regarding their prospects for development, the latter were intended to fall off the grid over time, since all kinds of new construction were prohibited there. Out of around 33,000 settlements 30,000 were identified for such disappearance [9]. The process of enlargement was subject to the development of agricultural production towards large mechanised farms and food processing complexes. A number of large model agriculture production farms with adjacent settlements were created. Thus, from very dispersed small rural settlements the pattern of distribution gradually changed toward centralisation. In terms of rural-urban population dynamics the country experienced a very significant decline in its rural population during the second half of the $20^{\text {th }}$ century to the beginning of the $21^{\text {st }}$ century, from $79 \%$ to $26 \%$ [10]. Currently, as of 2018 , out of some 9.4 million the rural population of Belarus constitute only 2 million [11] or around $21 \%$.

\section{Post-Soviet policy}

The period after the fall of the Soviet Union, i.e. 1990-early 2000s, was characterised by the general decline of all sectors of production, including agriculture; the trend of a decline of rural population also remained. The policy of agrogorodoks came in from 2005 , after the initial crisis of the country's development had been overcome. The aims and goals of such a policy were stated as follows: revitalisation and development of social and industrial sectors of Belarus rurality; ensuring sustainable agriculture production; increasing income of rural population; creating conditions for prestige of rural living [sic!] and improvement of demographics in rural areas; ensuring efficient agriculture and food production sufficient to cover internal needs and create export potential [1]. Thus, the policy emphasised its striving to reverse the decline of the rural population by attracting people to stay in newly created agrogorodoks, wherein urban standards of services would be provided.

The ambition of the programme in terms of services and infrastructure to ensure the said high-standard quality of life (reported to be mostly achieved [12]) were:

- establishment of 1481 agrogorodoks;

- 50k housing units; 
- full gasification;

- minimum $15 \mathrm{k} \mathrm{km}$ of power lines;

- full coverage of water supply;

- full coverage of telephone/mobile network;

- upgrading $4.3 \mathrm{k} \mathrm{km}$ of roads;

- $\min 85 \%$ children covered by school education;

- min 1 hospital per 10-15 km radius;

- 186 cultural facilities;

- 1.5 increase in public services;

- retail infrastructure: 800 units reopened; 140 new constructed, 210 renovated [1].

The features listed here were selected in terms of their relevance to the topic and are not exhaustive for other sectors such as renovation of agriculture infrastructure etc. had also been covered by the Programme.

Thus, as almost 1,500 agrogorodoks, being a new settlement type, have been created, how were they integrated into the administrative-territorial structure of the country and aligned with the national approach to the definition of rural and urban areas? Exploring this question, we are faced with not one, but rather a multitude of criteria employed in defining the different levels of the national spatial organisation, i.e. the gradation of territorial units from rural to urban settlements.

The following types of settlements are defined in the national regulation on administrative and territorial structure (names translated in the closest way possible):

- cities (population from minimum 50k for region level cities to minimum $6 \mathrm{k}$ for district level cities);

- urban type settlements (population from minimum $2 \mathrm{k}$ to minimum 500 for workers settlements);

- rural settlements (minimum population size is not defined) [13].

The regulation specifies further the criteria given for their distinction:

- population size;

- level of development and specialisation of industrial and social infrastructure;

- state functions performed on respective territories [13].

Thus, apart from a minimum population size, each settlement type is described in terms of its functions, facilities and infrastructure development. The regulation also provides the possibility to bypass the minimum population size in classifying a settlement under a certain type in cases where such a settlement "has a potential to population growth" and possesses other qualities attributable to this type [13].

The agrogorodok type is placed into the category of rural settlement therefore no minimum population size is determined for it. However, the naming creates confusion, for the very term agrogorodok contains the word gorodok, in its title, that is, "small town", whereas in the state classification it will still be called a rural settlement. Moreover, as we will see further, some agrogorodoks over time acquire quite large populations - up to 6,000 . The question then arises, whether such agrogorodoks will add to urbanisation and a decline of rural population by changing their status to "urban type settlements" or whether their rural status will remain.

Leaving aside the population size, what role does the access to services and facilities play in agrogorodoks? Could they be defined as "urban", bypassing the population limit solely based on functions, facilities and quality of life? What infrastructure is set out to bring urban standards into rural life in agrogorodoks? There is defined for this partic- 
ular type of settlement a check-list of obligatory elements/facilities of social, health, water management, energy and other infrastructures and services. The following items are listed there:

- secondary school;

- kindergarten;

- water management facilities: iron removal station; water tower; sewage treatment units;

- health care facility;

- cultural/community centre;

- sports facilities;

- supermarket;

- public catering/food service facility;

- domestic/household/utility services unit;

- public baths [14].

This level of provision of infrastructure is conceived as ensuring the said "high [here: compared to urban] standard of living" [1] and aimed at attracting residents from urban areas to settle in rural ones. Apart from infrastructure, what else of urban quality could the physical environment of agrogorodoks offer? If we turn our attention to the physical environment, i.e. some features of construction and planning, to compare it to the urban environment, do agrogorodoks add up to urban typologies, be it in housing or street network types or otherwise?

\section{The agrogorodok settlement structure}

The agrogorodoks were not constructed from scratch as entirely new settlements; rather, they were created from earlier settlements based on their centrality for the area, that is, their role in agriculture production, location in the region, ability to serve adjacent territories, already existing transport infrastructure etc. [1]. Therefore, in most cases only new housing has been constructed while public buildings or facilities have been housed in already-existing (in some cases renovated) building stock (although a certain amount of new public buildings have been constructed as well). Moreover, at the same time many buildings performing the same functions (schools, kindergartens etc.) in adjacent villages which were not classified as centres, was abandoned.

In terms of street network typology, the spatial analyses as conducted by lgor Malkov [15] identified 5 types of street networks based on different planning nodes (Figure 1.). However, given that agrogorodoks are created on the basis of already existing settlements, the street patterns as well as functional zoning, location of agriculture industry facilities etc. in many ways have been heavily affected by the regional feature, previous planning and development history. Thus, in most cases the plan of an agrogorodok will combine from 2 to 3 different types of street networks [15].

Further, the agrogorodoks, which are located in urbanised regions near core administrative centres of the regions will commonly have a regular street pattern typical of urban settlements [15]. The population of such agrogorodoks will also be quite large, reaching as many as up to 6,000 inhabitants [15]. The same will be applicable to relatively large rural settlements (1,500-3,000k), which experienced intensive development in the 1960-1970s [15]. These will also feature distinct type of housing, i.e. not only individual or row houses, but also some several-stories high apartment blocks, which belong rather to the urban milieu. 


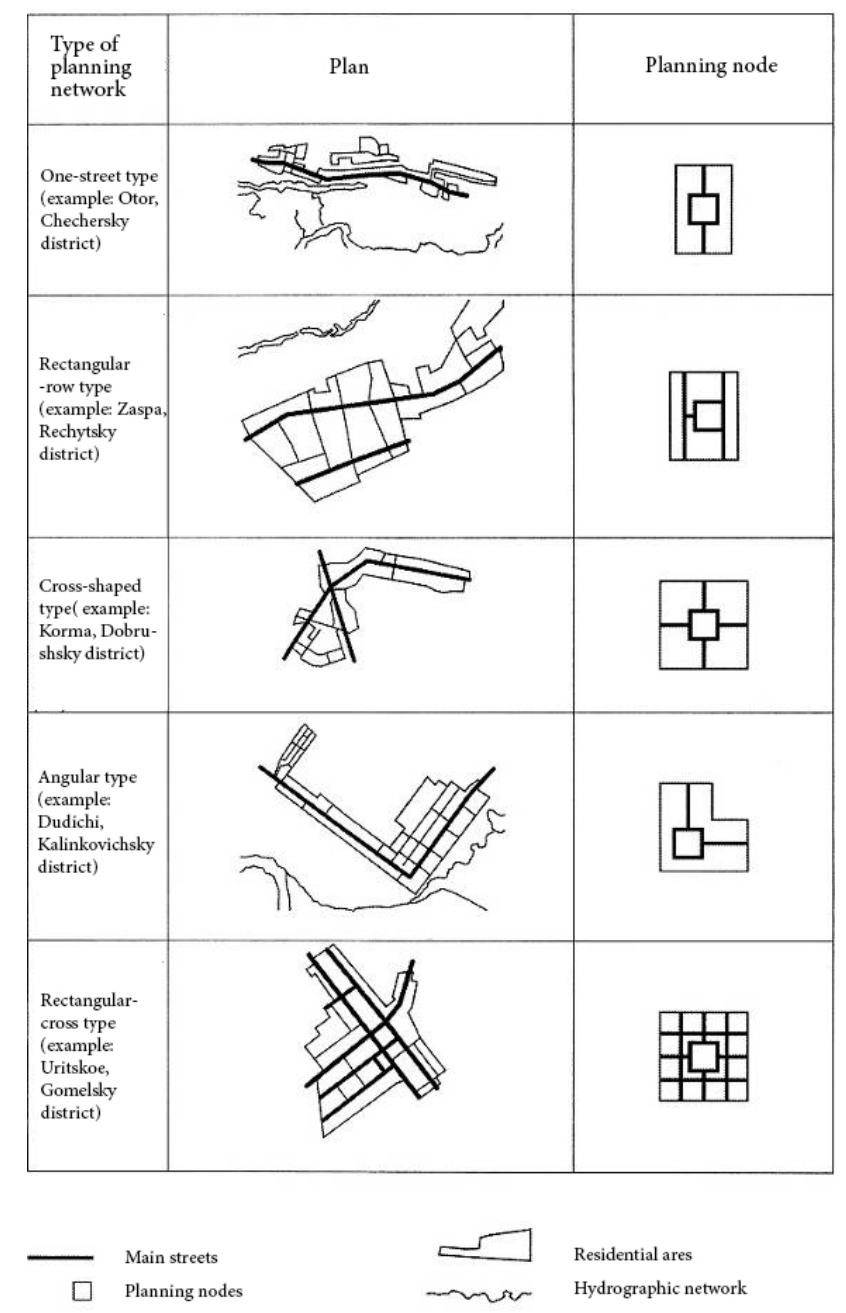

Figure 1: The network analysis of agrogorodoks. Source: [15].

To elaborate on housing types which appear in agrogorodoks across the country, the common feature of all will be standardised typical designs and rather poor quality of construction caused mostly by the need to reduce construction costs. The use of such standardised typical designs approved by the government is obligatory across all agrogorodoks [16]. Thus, the policy of housing construction in agrogorodoks gave birth to 66 typical or model designs for individual houses with improved plans as produced and approved by state planning and design bodies [16], thus contributing to development of a housing typology at the national level. The quality of construction work, materials and the very typical plans for houses etc. have aroused many complaints from new residents and users. A common topic in media devoted to life and conditions in newly constructed agrogorodoks would feature such complaints and stories of struggles to fix construction flaws and fights for decent houses after they have been officially finished and handed over to new residents [17]. The environment created by streets of standard houses does not provide much aesthetic attraction either. Therefore, it's highly questionable if such an approach is appropriate for the creation of a good-quality highstandard attractive environment in such settlements such as to stop rural inhabitants being drawn to cities (which is also articulated as one of goals of the policy). 


\section{Questions and conclusions}

The public facilities and costs of maintenance point to yet another problem that could be expressed in economic terms as the minimum efficient size, that is, that the need to be efficient or sound in economic terms will require a densification of population. Will it imply then the return to the demographics approach to urbanisation (and its inevitability), meaning the need for density/agglomeration/high concentration of population for the infrastructure not to be dependent on state subsidies? This need for concentration had already been recognised throughout the policy for enlargement/consolidation of rural settlements as referred to above. Could then the establishment of agrogorodoks be seen as a continuation of such an enlargement policy and if so, in which ways? Firstly, they are conceived as centres of services not only for local residents but for those from surrounding territories, meaning a certain optimisation/centralisation of otherwise dispersed small settlements. Further, parallel to the establishment of new schools etc. in agrogorodoks the process of the closure of small under-filled schools in adjacent areas is underway; therefore, smaller settlements are pushed toward depopulation.

Further, in terms of organisation of agricultural production (which is not explored in depth here) it should be mentioned that agrogorodoks are also the means for the centralisation of machinery assets for farmers/cooperatives so as to benefit from economies of scale and shared agricultural (inter alia) infrastructure. Even further, the creation of agrogorodoks has not been conceived as a more equitable distribution of population across agricultural areas or the establishment of new points of development across scarcely populated areas. On the contrary, does the policy of putting agrogorodoks into already established centres of rural areas reinforce the tendencies towards a larger population size of rural settlements and hence their urbanisation? That is, if the policy of agrogorodoks is to lead to centralisation, consolidation and prospective growth of otherwise dispersed and small-scale rural settlements into bigger-scale settlements, would it mean their urbanisation since they would acquire a) a population size attributed to a city and b) a level of infrastructure/urban standard of services - hence the only attribute to designate them as rural would be a structure of employment, meaning predominating agriculture production?

We have got used to accept such commonplace slogans as "the future is urban" seeing rural on its way to extinction while urbanisation is triumphantly taking over the planet. However, is it the only possible one-way road of moving forward or is there a room for side-ways or connecting roads to bind rural and urban together in more harmonious unity than the one of exploitation or superiority-inferiority? Is it possible to conceptualise, in a meaningful and clear way, the dichotomy of rural vs. urban? If to place a story of agrogorodoks within the wider context, not mentioning its first priority of rural revitalisation to save agriculture production for the sake of national food security, could we see it as an attempt to find such a side-ways route or is it a voluntary, hence doomed, attempt to reverse the mainstream path? This is also a way to open up a discussion of policy dimension, decision-making in spatial planning and its implications on actual landscapes.

\section{Brief resume}

Liudmila Slivinskaya. Completed her bachelor studies in Law and Political Science and holds a Master degree in Political Science; she wrote her master thesis on national identity as a political construct. She started her career in international cooperation in higher education as a grant writer 
and project manager with 5 years of work experience as project manager and local coordinator for a number of projects under EU-funded programmes. Member of NGO "Minsk Urban Platform". Currently continuing studies in interdisciplinary master course on urban development in Germany. Contributor to Mundus Urbano blog https://medium.com/@mundusurbano. Research interests include strategic urban planning and city development policies; theory and history of urban planning; post-socialist urban transformations.

\section{References}

1. ГОСУДАРСТВЕННАЯ ПРОГРАММА ВОЗРОЖДЕНИЯ И РАЗВИТИЯ СЕЛА НА 2005 - 2010 ГОДЫ [State Programme for Rural Revival \& Development for the years 2005-2010] (2005). Presidential Decree $n^{\circ} 150$ [25 March], Republic of Belarus. Retrieved from: http://www.mshp.gov.by/programms/fb78a49247bfa46c.html [available on 5 June 2018].

2. KOOLHAAS, R. 2012 [April 25]. Countryside. Annotated slideshow [Public lecture held at the Stedelijk Museum, Amsterdam). Retrieved from: http://oma.eu/lectures/countryside [available on 1 June 2018].

3. MALLICK, S. [2013]. Lecture 18: Rural-Urban Continuum: Meaning and Context. [Lecture to online course "Introduction to Sociology / Module 3: Social Structure and Social Change", Indian Institute of Technology Guwahati / NPTEL - Indian National Programme on Technology Enhanced Learning]. Retrieved from: http://nptel.ac.in/courses/109103023/download/Lecture\%2018.pdf [available on 1 June 2018].

4. UNITED NATIONS, DEPARTMENT OF ECONOMIC AND SOCIAL AFFAIRS, POPULATION DIVISION, 2014. World Urbanisation Prospects: The 2014 Revision, Highlights (ST/ESA/SER.A/352), New York, United Nations. Retrieved from: https://esa.un.org/unpd/wup/publications/files/wup2014-highlights.pdf [available on 5 June 2018].

5. ORGANISATION FOR ECONOMIC COOPERATION AND DEVELOPMENT, 2005. Glossary of Statistical Terms: Urban Population. [Online]. Retrieved from: https://stats.oecd.org/glossary/detail.asp?ID=6342 [available on 5 June 2018].

6. UNITED NATIONS, DEPARTMENT OF ECONOMIC AND SOCIAL AFFAIRS, STATISTICS DIVISION, 2017. Principles and Recommendations for Population and Housing Censuses (ST/ESA/STAT/SER.M/67/Rev.3), New York, United Nations. Retrieved from: https://unstats.un.org/unsd/demographic-social/Standardsand-Methods/files/Principles_and_Recommendations/Population-and-HousingCensuses/Series_M67rev3-E.pdf [available on 5 June 2018].

7. DIJKSTRA, L.; POELMAN, H. 2014. Regional Working Paper 2014. A harmonised Definition of Cities and Rural Areas: The New Degree of Urbanisation, (Working Papers: WP 01/2014), European Commission Directorate-General for Regional and Urban Policy (DG REGIO). Retrieved from: http://ec.europa.eu/regional_policy/sources/docgener/work/2014_01_new_urban.pdf [available on 5 June 2018].

8. О Государственной программе развития аграрного бизнеса в Республике Беларусь на 2016-2020 годы и внесении изменений в постановление Совета Министров Республики Беларусь от 16 июня 2014 г. $n^{\circ} 585$ [About the state program of development of the agricultural business in the Republic of Belarus for the years 2016-2020 and amendments to the Decree of the President of the Republic of Belarus of June 16, $2014 n^{\circ}$ 585] (2016). Presidential Decree $n^{\circ} 196$ [11 
March], Republic of Belarus. Retrieved from: http://www.pravo.by/document/?guid=3871\&p0=C21600196 [available on 5 June 2018].

9. KHACHATRIANTS, K.K.; VASHKEVICH, V. 2010. Сельский поселок - центр первичной территориальной системы [Urban Settlement - centre of primary territorial system], Minsk, BNTU. Retrieved from: https://rep.bntu.by/handle/data/5084 [Available on 5 June 2018].

10. URBAN, М.M. 2013. "Беларусь в зеркале демографической статистики (вторая половина XX - начало XXI в.) [Belarus in the Mirror of Demographic Statistics (Second half of the $20^{\text {th }}$ - beginning of the $21^{\text {st }}$ century)]", Беларусь $n$ мировые экономические процессы [Belarus and the world economic processes], $\mathrm{n}^{\circ}$ 10: 167-176. Retrieved from: http://elib.bsu.by/handle/123456789/92425 [available on 5 June 2018].

11. NATIONAL STATISTICAL COMMITTEE OF THE REPUBLIC OF BELARUS, 2018. Total population of Belarus as of January 01, 2018. Retrieved from: http://www.belstat.gov.by/ofitsialnaya-statistika/ssrd-mvf_2/natsionalnayastranitsa-svodnyh-dannyh/naselenie_6/chislennost-naseleniya1_yan_poobl/ [available on 5 June 2018].

12. MINISTRY OF ECONOMICS OF THE REPUBLIC OF BELARUS, 2018. Инфоормация о реализации государственных программ / Общие итоги реализации [Data on State Programmes. Overall outcomes of implementation]. Online. Retrieved from: http://www.economy.gov.by/ru/obs4_itogi-ru/ [available on 5 June 2018].

13. Закон РБ Об административно-территориальном устройстве Республики Беларусь [On the Administrative-Territorial Structure of the Republic of Belarus] (1998) [5 June]. Law of the Republic of Belarus $n^{\circ}$ 154-3. Retrieved from: http://kodeksy-by.com/zakon_rb_ob_administrativno-territorialnom_ustrojstve.htm [available on 5 June 2018].

14. Об утверждении перечня объектов агрогородков [On Approval of List of Facilities for Agrogorodoks], 2015 [1 December]. Act of the Ministry of Architecture and Construction of the Republic of Belarus $n^{\circ} 225$ Retrieved from: http://pravo.newsby.org/belarus/postanov16/pst491.htm [available on 5 June 2018].

15. MALKOV, I. 2007. "Планировочные структуры агрогородков и их классификация [Planning Structures of "Agrogorodoks" and their typology]", Архитектура и строительство [Architecture and Construction (Minsk)], vol. 187, $\mathrm{n}^{\circ}$ 8: n.p. Retrieved from: https://ais.by/story/1312 [available on 5 June 2018].

16. NAZARUK, V. 2007. "Действенные меры - конкретный результат" [Effective measures - tangible results], Архитектура и строительство [Architecture and Construction (Minsk)], vol. 187, $n^{\circ}$ 8: n.p. Retrieved from: https://ais.by/story/1306 [available on 5 June 2018].

17. KOZLOVICH, N.; SOBOLEV, A. 2012. Фоторепортаж: можно ли выжить в идеальном белорусском агрогородке? [Photo-reportage: Is it possible to survive in the ideal Belarusian "agrogorodok"?]. [Online]. Onliner.by. Retrieved from: https://people.onliner.by/2012/08/24/agro [available on 5 June 2018]. 